\title{
The Finnish Paper Workers' Union: Becoming a Paper Tiger? Collective bargaining, Wage developments and Union Density between 1980 and 2005
}

\author{
Paul J. Jonker ${ }^{*}$
}

The decisions taken by the Finnish Paper Union concerning collective bargaining goals have pinned down the union on a track which makes the union defend acquired rights only instead of focusing on future developments in the paper industry at a European and global level. In this article, the history of Paperiliitto will be analyzed, in particular through the goals set for the collective bargaining between 1980 and 2005. It is shown through a limited regression analysis that Paperiliitto does not currently have many opportunities to influence the union density. This article argues that Paperiliitto has concentrated too much on catering for its own constituency, which at present leads to increasingly confrontational industrial relations in the sector, after a long period of calm. [Article copies available for a fee from The Transformative Studies Institute. E-mail address: journal@transformativestudies.org Website:

http://www.transformativestudies.org (C2009 by The Transformative Studies Institute. All rights reserved.]

KEYWORDS: Labour Union, Paper Industry, Union Density, PathDependency.

\section{INTRODUCTION}

The Finnish Paper Union Paperiliitto celebrated its 100th anniversary in 2006; 100 years earlier it was founded as a labour union with a mission to battle against capitalism. Although Paperiliitto celebrated its jubilee in 2006, one year earlier Paperiliitto had to 'battle capitalism' to preserve its

\footnotetext{
* Paul Jonker is currently a Ph.D.-student in the Department of Sociology in the University of Turku, Finland. His main research interest is labour union representativeness in France, Finland and the Netherlands. Other research interests include labour market gender- and minority-policies. Address correspondence to: Paul Jonker, M.A., Department of Sociology, University of Turku, FIN-20014, Finland; tel. +358 2333 5714; e-mail: paul.jonker@utu.fi.
} 